Suparti, Lailia Zubaidah. (2018). Pertumbuhan Bibit F0 Jamur Tiram dan Jamur Merang pada Media Alternatif Tepung Biji Jewawut dengan Konsentrasi yang Berbeda. Jurnal Bioeksperimen. Vol. 4 (2) Pp. 52-60. Doi: 10.23917/ bioeksperimen.v4i1.2795

\title{
Pertumbuhan Bibit Fo Jamur Tiram dan Jamur Merang Pada Media Alternatif Tepung Biji Jewawut dengan Konsentrasi yang Berbeda
}

\author{
Suparti, Lailia Zubaidah \\ Program Studi Pendidikan Biologi FKIP Universitas Muhammadiyah Surakarta \\ eE-mail:sup168@ums.ac.id
}

\begin{abstract}
Abstrak
Biji-bijian merupakan salah satu sumber karbohidrat yang dibutuhkan untuk pertumbuhan miselium jamur merang dan tiram. Tepung biji jewawut memiliki kandungan karbohidrat $(68,32 \mathrm{~g})$ dalam $100 \mathrm{~g}$, sehingga bisa digunakan sebagai sumber nutrisi pertumbuhan jamur pangan. Oleh karenanya dapat digunakan sebagai pengganti kentang untuk pembuatan bibit FO. Sedangkan kentang mengandung 19,10 g karbohidrat. Penelitian bertujuan untuk mengetahui pertumbuhan miselium bibit FO jamur tiram dan jamur merang yang ditumbuhkan pada media tepung jewawut dengan konsentrasi yang berbeda. Metode penelitian menggunakan metode eksperimen dengan Rancangan Acak Lengkap (RAL) pola faktorial dengan 2 faktor, yaitu konsentrasi media tepung biji jewawut (J) dan jenis jamur (T). Teknik analisis data menggunakan deskriptifkualitatif. Berdasarkan hasil penelitian, didapatkan rerata pertumbuhan miselium jamur terbaik pada konsentrasi tepung biji jewawut 15\%, indukan jamur merang, yaitu dengan diameter 3,1 cm dan miselium yang rapat. Sedangkan rerata pertumbuhan miselium jamur terendah pada Konsentrasi tepung biji jewawut 20\%, indukan jamur tiram dengan miselium yang tidak mengalami pertumbuhan.
\end{abstract}

Kata kunci: tepung biji jewawut, jamur tiram, jamur merang, pertumbuhan miselium

\begin{abstract}
Grains are one of the carbohydrate sources needed for the growth of edible mushroom mycelium and oysters. Jawawut seed flour has carbohydrate $(68.32 \mathrm{~g})$ in $100 \mathrm{~g}$, so it can be used as a nutritional source for the growth of food fungi. Therefore it can be used as a substitute for potatoes for making FO seeds. While potatoes contain $19.10 \mathrm{~g}$ of carbohydrates. The study aimed to determine the growth of mycelium FO seedlings of oyster mushrooms and mushroom mushrooms grown on barley flour media with different concentrations. The research method used an experimental method with a completely randomized design (CRD) factorial pattern with 2 factors, namely the concentration of barley seed flour media (J) and type of fungus (T). Data analysis techniques using qualitative descriptive. Based on the results of the study, it was found that the best growth rate of fungal mycelium was at a concentration of 15\% barley seed flour, broodstock broodstock, ie with a diameter of $3.1 \mathrm{~cm}$ and a tight mycelium. While the lowest average growth of fungal mycelium at $20 \%$ barley seed flour concentration, broodstock oyster mushrooms with mycelium that did not experience growth.
\end{abstract}

Keywords: foxtail millet flour, straw mushroom, oyster mushroom, mycelium growth

\section{Pendahuluan}

Budidaya jamur merupakan usaha memperbanyak jamur dengan cara menanamnya pada media buatan yang sesuai dengan tempat hidup jamur tersebut. Secara umum proses budidaya jamur meliputi empat tahap yaitu pembuatan biakan murni, biakan induk, bibit induk dan bibit produksi (Suparti, 2017). Biakan murni $\left(\mathrm{F}_{0}\right)$ adalah asal mula bibit diperoleh dari pemilihan jamur yang baik. Jamur kemudian diisolasi sporanya dalam keadaan steril. Isolasi ini dilakukan pada cawan petri berisi media PDA. Spora kemudian berkecambah dan membentuk hifa, hifa semakin kompleks kemudian membentuk miselium. Salah satu tahap yang paling penting dalam pembuatan biakan murni yaitu media biakan.

Menurut Alam, dkk (2010), pembibitan jamur tiram terbatas pada pertumbuhan miselium. Kondisi optimal yang dibutuhkan untuk pertumbuhan miselium jamur tiram 
adalah suhu $25-30^{\circ} \mathrm{C}$, kondisi $\mathrm{pH}$ medium berkisar 6-8. Nutrisi yang dibutuhkan untuk pertumbuhan jamur tiram antara lain karbohidrat, protein, mineral dan vitamin (Djarijah, 2001), sedangkan untuk pertumbuhan dan perkembangan jamur merang membutuhkan suhu udara $25-37^{\circ} \mathrm{C}$, serta kualitas nilai gizi sumber bahan organik sebagai substrat untuk menumbuhkan miselium/ hifa bibit dan memproduksi tubuh buah (Quimio, 1981).

Medium biakan murni jamur yang paling sering digunakan adalah medium Potato Dekstrose Agar (PDA) (Chang dan Quimio, 1989). Sumber nutrisi medium PDA berasal dari air rebusan kentang dimana kentang mengandung karbohidrat yang tinggi. Karbohidrat berfungsi sebagai sumber karbon sehingga dapat menambah nutrien pada media tanam. Karbon merupakan unsur penting yang sangat dibutuhkan jamur sebagai sumber energi dalam menjalankan aktivitas metabolismenya. Penambahan karbohidrat yang lebih banyak pada media tanam jamur dapat mempercepat munculnya tubuh buah dan menambah berat basah tubuh buah jamur (Ahmad, 2014). Media yang biasa digunakan dalam pembuatan bibit F0 adalah Potatoes Dextrose Agar (PDA). Media ini menggunakan kentang sebagai sumber nutrisinya. Berdasarkan penilitian Singgih (2015), dalam $100 \mathrm{~g}$ kentang terkandung 19,10 g karbohidrat, 2,00 g protein, 0,10 g lemak, $11,00 \mathrm{mg}$ kalsium, $56 \mathrm{mg}$ fosfor dan $1,00 \mathrm{mg}$ besi.

Masalah yang sering dihadapi dari penggunaan media PDA ini adalah nilai jual kentang yang dianggap mahal oleh masyarakat. Untuk itu diperlukan bahan lain yang mempunyai nilai karbohidrat yang tinggi sebagai pengganti kentang, salah satunya adalah umbi-umbian lokal.

Umbi - umbian lokal merupakan jenis umbi yang mempunyai kandungan karbohidrat yang cukup tinggi, sehingga mampu mencukupi kebutuhan karbohidrat untuk pertumbuhan jamur, misalnya Ubi talas memiliki keunggulan yaitu kemudahan patinya untuk dicerna. Hal ini disebabkan talas memiliki ukuran granula pati yang sangat kecil yaitu 1-4 $\bigotimes \mathrm{m}$ (Suparti $\mathrm{dkk}$, 2017). Ubi talas mengandung pati yang mudah dicerna sebanyak 18,2\%, sukrosa serta gula preduksinya $1,42 \%$ dan karbohidrat sebesar $23,7 \%$. Selain mempunyai harga yang ekonomis, ubi talas juga lebih mudah ditemukan di berbagai daerah. Sehingga untuk pembuatan media tersebut akan lebih mudah dilakukan.

Berdasarkan penelitian Sugeng Handiyanto, dkk (2013), menyatakan bahwa kecepatan pertumbuhan miselium cenderung semakin meningkat seiring dengan meningkatnya konsentrasi air cucian beras. Hasil penelitian ini menyatakan bahwa kecepatan pertumbuhan miselium yang tertinggi ialah pada medium air cucian beras konsentrasi 90\%, kemungkinan di dalam air cucian beras konsentrasi $90 \%$ terdapat kandungan nutrisi yang paling optimum dalam mencukupi kebutuhan nutrisi jamur tiram dibandingkan dengan konsentrasi lain. Pada air cucian beras terdapat kandungan nutrisi yang melimpah di antaranya karbohidrat berupa pati (85-90\%), protein glutein, selulosa, hemiselulosa, gula dan vitamin yang tinggi.

Media tumbuh merupakan aspek penting yang menetukan tingkat keberhasilan budidaya jamur. Media tanam yang dibutuhkan jamur tiram putih harus mengandung nutrisi dianataranya lignin, karbohidrat (selulosa dan glukosa), protein, serat, vitamin, dan nitrogen. Media tersebut dapat ditemukan pada serbuk gergaji kayu, bekatul, kapur, jerami, sekam, tepung beras, dan kapur (Cahyana, dkk , 2006). Selulosa merupakan bahan yang kaya akan kandungan karbon yang berfungsi dalam proses fermentasi mikroba. Kayu yang keras dan berdaun lebar mengandung selulosa yang dibutuhkan oleh jamur. Bekatul berfungsi sebagai sumber nutrisi, karbohidrat, dan sumber energi. Sedangkan $\mathrm{CaCO}_{3}$ berfungsi sebagai pengatur $\mathrm{pH}$ atau menjaga keasaman media dan sebagai sumber mineral. Kandungan $\mathrm{Ca}$ berfungsi menetralisir asam yang dikeluarkan oleh miselium yang bisa menyebabkan $\mathrm{pH}$ lingkungan menjadi rendah.

Bibit F0 diperoleh dari spora yang 
membentuk hifa, berupa benang-benang halus. Hifa akan tumbuh semakin kompleks kemudian membentuk miselium jamur. Miselium akan membentuk cabang-cabang pada permukaan media dan tumbuh sempurna menutupi seluruh media (Achmad, 2011). Berdasarkan penelitian Pertiwi (2017), bibit F0 jamur tiram dan jamur merang dapat tumbuh pada media ekstrak, bubur dan tepung dengan bahan dasar singkong. Hasil pertumbuhan miselium terbaik yaitu pada media ekstrak dengan diameter 2,25 $\mathrm{cm}$ pada jamur tiram dan pada media tepung dengan diameter mencapai $8,75 \mathrm{~cm}$ pada jamur merang.

Jamur tiram dan jamur merang termasuk dalam 4 spesies jamur konsumsi yang paling diminati oleh masyarakat. Jamur tiram dan jamur merang juga memiliki kemampuan beradaptasi yang tinggi, sehingga menjadikan kedua jamur ini mudah untuk dibudidayakan. Berdasarkan penelitian Betharia (2017), miselium jamur tiram dan jamur merang sudah mengalami pertumbuhan sejak hari ketiga dan sudah memenuhi cawan petri setelah hari ketujuh inokulasi pada media alternatif dengan bahan dasar biji nangka. Berdasarkan penelitian Thongklang (2010), karbohidrat merupakan nutrisi yang paling penting untuk pertumbuhan miselium jamur. Bii-bijian mengandung karbohidrat, seperti pati dan gula sederhana yang dapat digunakan secara langsung sebagai nutrisi bagi pertumbuhan miselium jamur (Utoyo, 2010). Salah satu biji-bijian yang mengandung karbohidrat tinggi adalah biji jewawut.

Selama ini, biji jewawut hanya dimanfaatkan sebagai pakan burung. Sedangkan dalam budidaya jamur, media biji jewawut telah dimanfaatkan untuk media bibit F2 (Sunarmi, 2010). Biji jewawut juga dapat dimanfaatkan sebagai bahan makanan, namun biasanya biji ini diolah terlebih dahulu menjadi tepung. Berdasarkan penelitian Setiadi (2015), substitusi tepung jewawut kedalam nugget ayam dapat meningkatkan kadar Fe (zat besi) dalam nugget ayam. Berdasarkan penelitian Wijaya (2010), bahwa jewawut yang dibuat tepung akan mengandung karbohidrat sebanyak 68,32\%, kadar air 12,86\%, kadar abu 2,67\%, kadar lemak 9,03\%, kadar protein 7,12\% dan kadar serat $10,86 \%$. Kandungan karbohidrat yang tinggi dalam tepung biji jewawut berpotensi dapat dimanfaatkan sebagai alternatif pengganti media PDA pada pembibitan F0 dari jamur tiram dan jamur merang.

Penggunaan media tepung dalam pembuatan bibit F0 memiliki keunggulan berupa daya simpan media yang relatif lama. Berdasarkan penelitian Yusron (2017), kentang hitam dapat dimanfaatkan sebagai media alternatif untuk pertumbuhan miselium bibit F0. Hasil pertumbuhan miselium terbaik yaitu pada media tepung, dimana miselium jamur tiram mencapai diameter $2,15 \mathrm{~cm}$ dan jamur merang mencapai $8 \mathrm{~cm}$. Selain itu, berdasarkan penelitian Lesmana (2016), konsentrasi tepung beras putih yang dapat digunakan sebagai campuran media PDA sebagai media pertumbuhan miselium jamur yaitu 10\%, $20 \%$ dan 30\%. Hasil pertumbuhan miselium jamur terbaik adalah dengan menggunakan perbandingan konsentrasi $20 \%$.

Sebelumnya telah dilakukan pra penelitian menggunakan berbagai konsentrasi tepung yaitu $10 \%$, 20\% dan 30\%. Namun, pada konsentrasi $30 \%$ media yang dihasilkan tidak sesuai dengan yang diharapkan, karena media menjadi terlalu padat sehingga akan menyulitkan peneliti saat penuangan media kedalam cawan petri. Maka, peneliti mengubah perbandingan konsentrasi tepung jewawut menjadi $10 \%, 15 \%$ dan $20 \%$. Berdasarkan latar belakang diatas, peneliti tertarik untuk melakukan penelitian tentang pertumbuhan miselium bibit F0 jamur tiram dan jamur merang pada media alternatif tepung jewawut dengan konsentrasi yang berbeda.

\section{Metode}

Penelitian dilakukan di Laboratorium Budidaya Jamur Universitas Muhammadiyah Surakarta. Penelitian ini merupakan penelitian dengan metode eksperimen yang menggunakan RAL (Rancangan Acak Lengkap) dengan faktor perlakuan faktorial serta menggunakan satu 
kali pengulangan. Parameter yang diamati pada penelitian ini adalah diameter dan kerapatan miselium. Tehnik analisis data yang digunakan adalah deskriptif kualitatif.

Alat yang digunakan dalam penelitian ini antara lain: autoclave, blender, oven, erlenmeyer, gelas ukur, pinset, scalpel permanen, timbangan digital, lampu bunsen, kassa, kaki tiga, cawan petri dan LAF. Sedangkan bahan yang dibutuhkan antara lain: biji jewawut, indukan jamur tiram dan jamur merang, aquades, gula, agar-agar, alumunium foil, plasctic wrap, alkohol 70\%, karet gelang, kapas dan kertas payung.

Pelaksanaan penelitian diawali dengan sterilisasi alat, kemudian pembuatan media diawali dengan menimbang $10 \mathrm{~g}$ tepung biji jewawut, $90 \mathrm{ml}$ aquades untuk konsentrasi $10 \%, 15 \mathrm{~g}$ tepung biji jewawut, $85 \mathrm{ml}$ aquades untuk konsentrasi 15\%, $20 \mathrm{~g}$ tepung biji jewawut, $80 \mathrm{ml}$ aquades untuk konsentrasi
$10 \%$ serta 1,6 g agar-agar dan 2 g gula pada tiap konsentrasi. Kemudian memasukkan semua bahan kecuali agar pada tiap erlenmeyer sambil dihomogenkan dan dipanaskan, setelah suhu mulai naik memasukkan agar dan menghomogenkan sampai hampir mendidih. Kemudian mensterilisasi media yang diperoleh dan menuangkan pada cawan petri. Setelah itu, menginokulasi spora dari indukan jamur tiram dan jamur merang kedalam media dan diinkubasi pada suhu $22^{\circ} \mathrm{C}-28^{\circ} \mathrm{C}$ selama 7 hari.

\section{Hasil dan Pembahasan}

Berdasarkan hasil penelitian tentang pemanfaatan tepung biji jewawut sebagai media alternatif untuk pertumbuhan bibit F0 jamur tiram dan jamur merang, diperoleh hasil pertumbuhan miselium F0 jamur yang disajikan pada tabel 1.

Tabel 1. Rerata pertumbuhan miselium jamur tiram dan jamur merang pada media tepung biji jewawut dengan konsentrasi $10 \%, 15 \%$ dan $20 \%$ pada hari ke-3 dan ke-7

\begin{tabular}{|c|c|c|c|c|c|c|c|c|}
\hline \multirow{4}{*}{ Konsentrasi } & \multicolumn{8}{|c|}{ Pertumbuhan Miselium } \\
\hline & \multicolumn{4}{|c|}{ Hari ke-3 } & \multicolumn{4}{|c|}{ Hari ke-7 } \\
\hline & \multicolumn{2}{|c|}{ Jamur Tiram } & \multicolumn{2}{|c|}{ Jamur Merang } & \multicolumn{2}{|c|}{ Jamur Tiram } & \multicolumn{2}{|c|}{ Jamur Merang } \\
\hline & $\underset{(\mathrm{cm})}{\mathrm{d}}$ & $\begin{array}{c}\text { K (rapat/ } \\
\text { tidak } \\
\text { rapat) }\end{array}$ & $\underset{(\mathrm{cm})}{\mathrm{d}}$ & $\begin{array}{c}\text { K (rapat/ } \\
\text { tidak } \\
\text { rapat) }\end{array}$ & $\underset{(\mathrm{cm})}{\mathrm{d}}$ & $\begin{array}{c}\text { K (rapat/ } \\
\text { tidak } \\
\text { rapat) }\end{array}$ & $\underset{(\mathrm{cm})}{\mathrm{d}}$ & $\begin{array}{c}\mathrm{K} \text { (rapat } \\
\text { tidak } \\
\text { rapat) }\end{array}$ \\
\hline $10 \%$ & 0 & - & 1,4 & $\begin{array}{l}\text { Tidak } \\
\text { Rapat }\end{array}$ & 1,2 & $\begin{array}{l}\text { Tidak } \\
\text { rapat }\end{array}$ & 1,75 & Rapat \\
\hline $15 \%$ & 1,1 & Rapat & 2,25 & Rapat & 1,6 & Rapat & $3,1^{*}$ & Rapat \\
\hline $20 \%$ & 0 & - & 0.9 & $\begin{array}{l}\text { Tidak } \\
\text { Rapat }\end{array}$ & $0^{* *}$ & - & 1 & $\begin{array}{l}\text { Tidak } \\
\text { Rapat }\end{array}$ \\
\hline
\end{tabular}

d: Diameter, K: Kerapatan, *: Pertumbuhan paling cepat, ${ }^{* *}$ : Pertumbuhan paling lambat

Berdasarkan data tabel 1, pertumbuhan miselium jamur tiram hari ke-3 memiliki ratarata kecepatan tumbuh yang paling besar yaitu pada konsentrasi tepung jewawut 15\% dengan diameter miselium $1,1 \mathrm{~cm}$ dan memiliki kerapatan miselium yang rapat, sedangkan dua konsentrasi lainnya belum mengalami pertumbuhan. Kemudian pada hari ke-7 pertumbuhan miselium jamur tiram, memiliki rata-rata pertumbuhan yang paling besar juga pada konsentrasi tepung jewawut 15\% dengan diameter miselium $1,6 \mathrm{~cm}$ dan memiliki kerapatan miselium yang rapat, sedangkan pada konsentrasi tepung jewawut 10\% sudah mengalami pertumbuhan dengan diameter miselium $1,2 \mathrm{~cm}$ dan kerapatan miselium yang tidak rapat serta pada konsentrasi 20\% tidak mengalami pertumbuhan.

Pada jamur merang berdasarkan data tabel 1 , pertumbuhan miselium jamur merang hari 
ke3 memiliki rata-rata kecepatan tumbuh yang paling besar yaitu pada konsentrasi tepung jewawut $15 \%$ dengan diameter 2,25 $\mathrm{cm}$ dan memiliki kerapatan miselium yang rapat, sedangkan dua konsentrasi lainnya sudah mengalami pertumbuhan, namun lebih lambat. Kemudian pada hari ke-7 pertumbuhan miselium jamur merang memiliki rata-rata pertumbuhan yang paling besar, juga pada konsentrasi tepung jewawut $15 \%$ dengan diameter miselium $3,1 \mathrm{~cm}$ dan memiliki kerapatan miselium yang rapat, sedangkan pada konsentrasi tepung jewawut $10 \%$ sudah mengalami pertumbuhan dengan diameter miselium $1,75 \mathrm{~cm}$ dan kerapatan miselium yang rapat serta pada konsentrasi $20 \%$ juga mengalami pertumbuhan namun paling lambat dengan diameter $1 \mathrm{~cm}$ dan kerapatan miselium yang tidak rapat.

\section{Diameter pertumbuhan jamur merang dan jamur Tiram}

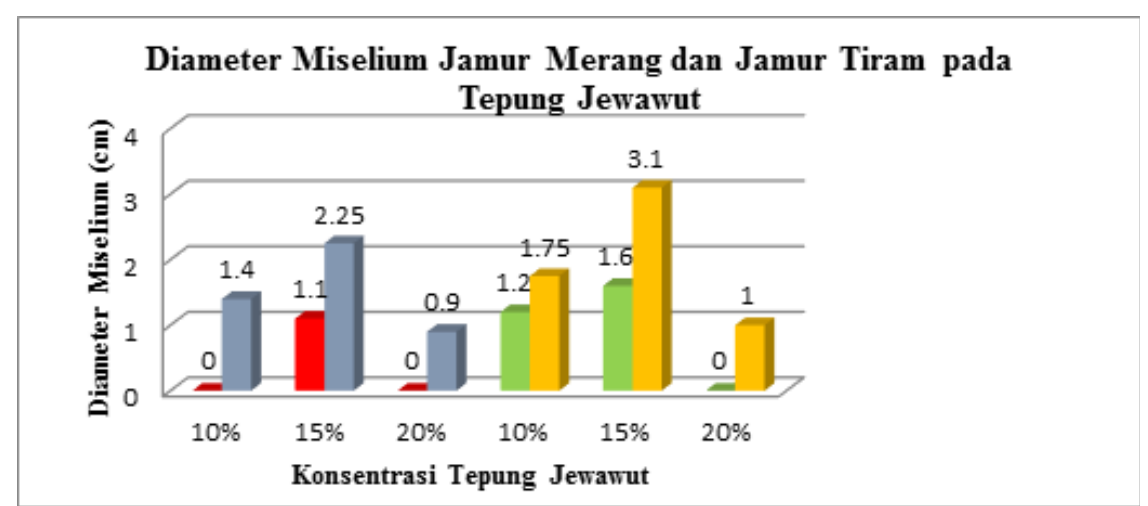

Gambar 1 Grafik pertumbuhan diameter miselium jamur tiram dan jamur merang pada media tepung jewawut

Berdasarkan gambar 1, diperoleh pertumbuhan diameter miselium jamur merang dan jamur tiram pada konsentrasi media $10 \%$ dan $20 \%$ memiliki ukuran yang lebih kecil dibanding miselium pada konsentrasi 15\%. Lebih kecilnya diameter miselium jamur merang dan jamur tiram yang tumbuh pada konsentrasi $10 \%$ dan $20 \%$ ini dimungkinkan karena ketidakcocokan media. Hal ini sejalan dengan penelitian Muyasarah (2017), spora yang berada pada lingkungan media yang cocok akan tumbuh dengan baik. Apabila lingkungan tidak tidak cocok maka spora jamur akan membutuhkan lebih banyak waktu untuk beradaptasi dan membentuk hifa.

Perbedaan pertumbuhan miselium jamur tiram dan jamur merang disebabkan karena adanya perbedaan konsentrasi tepung biji jewawut. Perbedaan ini menyebabkan adanya perbedaan nutrisidisetiapkonsentrasitepungnya. Hal ini sejalan dengan penelitian Handiyanto (2013), bahwa perbedaan konsentrasi air cucian beras dapat mempengaruhi kecepatan pertumbuhan miselium jamur karena terdapat perbedaan nutrisi pada masing-masing media. Pertumbuhan terbaik miselium jamur tiram dan jamur merang seperti pada gambar 1 yaitu pada konsentrasi media 15\% disebabkan karena nutrisi yang dibutuhkan miselium jamur tiram dan jamur merang untuk tumbuh terpenuhi sehingga pertumbuhan miselium bibit F0 jamur merang dan jamur tiram dapat optimal.

Faktor lain yang mempengaruhi lebih kecilnya ukuran diameter miselium jamur tiram dan jamur merang pada konsentrasi $10 \%$ dan $20 \%$ karena adanya perbedaan kadar air yang terkandung dalam media. Miselium jamur dapat tumbuh apabila media tumbuhnya memiliki kadar air yang berkisar antara 70\%75\% (Sumarsih, 2010). Sedangkan kadar air pada konsentrasi 10\% dimungkinkan terlalu banyak serta kadar air pada konsentrasi 20\% dimungkinkan terlalu sedikit, sehingga dapat menghambat pertumbuhan miselium jamur 
tiram. Hal ini sejalan dengan penelitian Seswati (2013), kadar air yang terlalu sedikit ataupun terlalu banyak dalam media miselium jamur tiram akan berpengaruh pada pertumbuhan miseliumnya karena dapat menghambat penyerapan nutrisi.

Nutrisi menjadi salah satu faktor yang menentukan pertumbuhan miselium jamur tiram dan jamur merang. Tepung jewawut selain memiliki kandungan nutrisi yang tinggi juga memiliki zat anti nutrisi seperti, tanin sebesar $0,06 \%$ dan asam fitat sebesar 2,91\%3,30\% (Badau, 2005 dan Herodian, 2011 dalam Soeka, 2017). Pengikatan nutrisi oleh zat anti nutrisi ini dapat menghambat penyerapan nutrisi oleh miselium jamur. Pada konsentrasi $10 \%$ dengan komposisi tepung biji jewawut yang lebih sedikit dimungkinkan zat antinutrisi didalamnya juga lebih sedikit, sedangkan pada konsentrasi 20\% memiliki komposisi tepung yang paling banyak sehingga zat antinutrisi didalamnya menjadi paling banyak sehingga pertumbuhan diameter miselium jamur merang paling lambat bahkan pada miselium jamur tiram tidak mengalami pertumbuhan.

Keuntungan penggunaan biji-bijian sebagai media pertumbuhan miselium jamur adalah terdapatnya kandungan karbohidrat, seperti pati dan gula sederhana yang dapat digunakan secara langsung sebagai nutrisi bagi pertumbuhan miselium jamur (Utoyo, 2010). Namun, tingginya kadar karbohidrat pada media tepung biji jewawut juga merupakan substrat yang baik bagi jasad renik sehingga akan memungkinkan terjadinya kontaminasi. Miselium jamur harus berwarna putih dan tumbuh dari jaringan yang diinokulasi (Achmad, 2011). Miselium jamur merang dan jamur tiram yang di inokulasi pada media tepung jewawut memang berwarna putih seperti yang terlihat pada gambar 2 dan 3. Namun, pada media yang telah diinokulasi mengalami kontaminasi, walaupun tidak sampai pada miselium jamur. Hal ini dimungkinkan tidak akan mempengaruhi kualitas miselium yang tumbuh, namun akan menghambat pertumbuhan miselium baik pada jamur merang dan jamur tiram.
Lambatnya pertumbuhan miselium jamur akibat adanya kontaminasi ini sejalan dengan penelitian Suparti (2017), bahwa kontaminasi dapat menyebabkan pertumbuhan miselium jamur melambat dan tidak menyebar. Kontaminasi dapat terjadi karena alat dan bahan yang digunakan kurang steril sehingga media yang digunakan terkontaminasi dan proses inokulasi jamur yang kurang steril. Kualitas indukan jamur yang tidak bagus juga akan mempengaruhi pertumbuhan miselium jamur sehingga dapat menyebabkan terjadinya kontaminasi. Indukan jamur merang yang digunakan saat inokulasi dimungkinkan memiliki kualitas yang lebih baik dibanding indukan jamur tiram sehingga pertumbuhan miselium jamur merang lebih baik.

Faktor yang mempengaruhi pertumbuhan miselium bibit F0 jamur tiram dan jamur merang yang lain seperti suhu, kelembapan, $\mathrm{O}_{2}$ dan $\mathrm{pH}$. Suhu yang dibutuhkan jamur tiram untuk pembentukan miselium adalah $20^{\circ} \mathrm{C}-30^{\circ} \mathrm{C}$ dengan kelembapan $80 \%-85 \%$. Pada jamur merang membutuhkan suhu 30$32^{\circ} \mathrm{C}$ dengan kelembapan $80 \%-90 \%$ untuk menumbuhkan miselium (Wiardani, 2010).

\section{Kerapatan}

Miselium jamur merang dan jamur tiram memiliki karakteristik kerapatan yang sama yaitu rapat. Tingkat kerapatan miselium akan semakin menurun jika bibit terus menerus diturunkan (Sainsjournal-fst11, 2015). Berdasarkan penelitian (Astuti, 2017), semakin tinggi kandungan karbohidrat maka semakin banyak nutrisi yang diserap oleh miselium sehingga miselium semakin rapat. Berdasarkan hasil penelitian yang disajikan pada tabel 2 , jamur tiram dan jamur merang memiliki miselium yang rapat. Namun, miselium jamur tiram dengan konsentrasi $10 \%$ dan jamur merang dengan konsentrasi 20\% tidak sejalan dengan teori dan penelitian yang terdahulu, dimana diperoleh miselium jamur yang tidak rapat. Hal ini disebabkan karena pertumbuhan miselium yang belum merata serta dimungkinkan akibat dari adanya kontaminasi sehingga terjadi 
persaingan dalam penyerapan nutrisi antara miselium jamur dengan kontaminan yang dapat menyebabkan kurangnya nutrisi pada miselium

jamur merang sehingga miseliumnya menjadi kurang rapat.

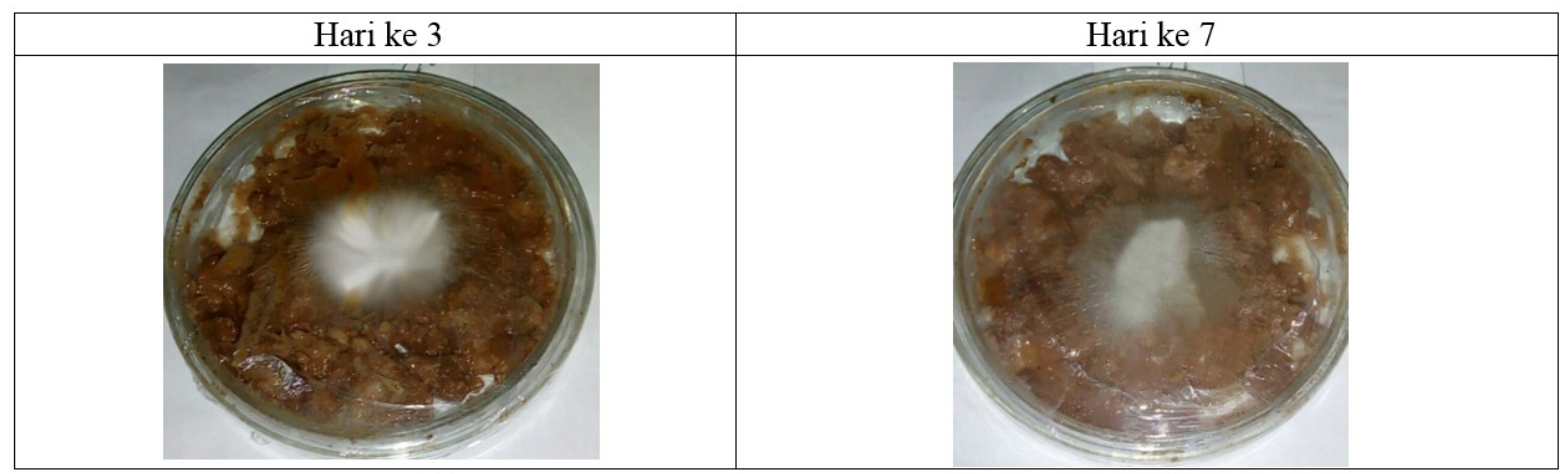

(a) (b)

Gambar 1. Pertumbuhan miselium jamur paling optimal dengan konsentrasi tepung jewawut $10 \%$ (a) jamur tiram dan (b) jamur merang

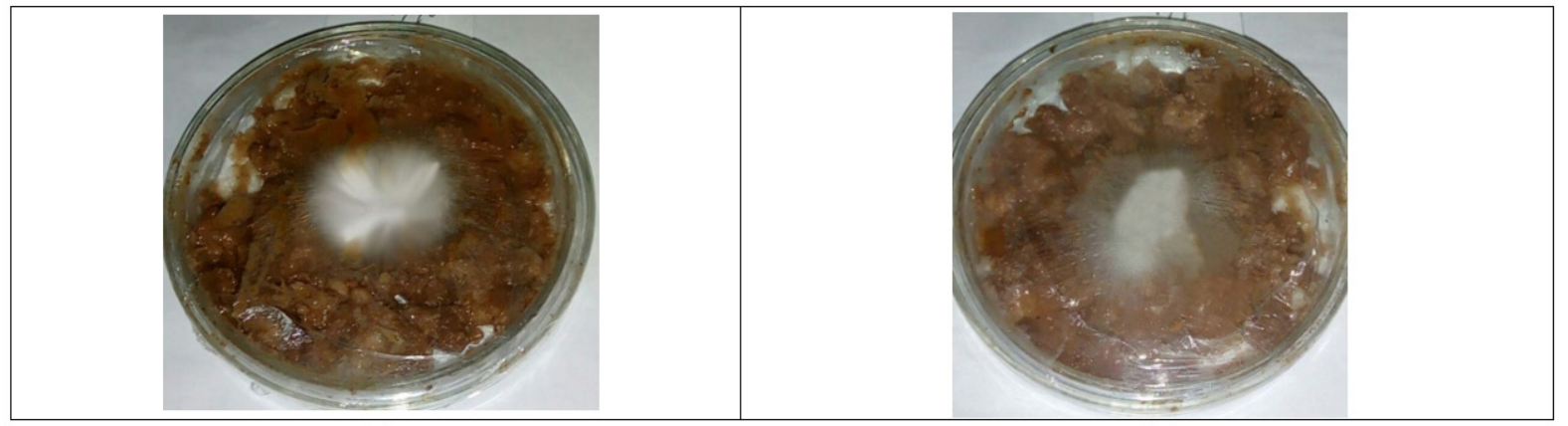

(a)

(b)

Gambar 2 Pertumbuhan miselium jamur paling optimal dengan konsentrasi tepung jewawut 15\% (a) jamur tiram dan (b) jamur merang

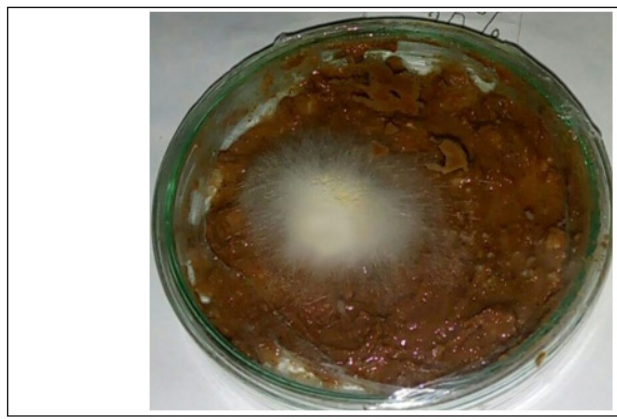

(a)

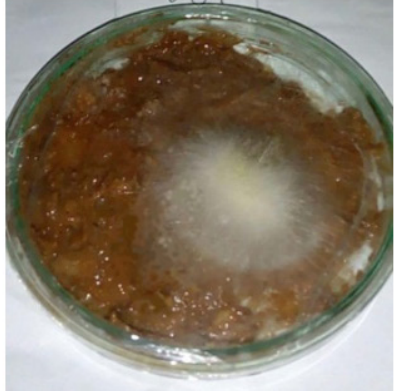

(b)

Gambar 3 Pertumbuhan miselium jamur yang tidak optimal dengan konsentrasi tepung jewawut 20\% (a) jamur tiram dan (b) jamur merang

\section{Simpulan}

Miselium bibit F0 jamur tiram dan jamur merang dapat tumbuh pada media alternatif tepung biji jewawut dengan konsentrasi yang berbeda. Pertumbuhan miselium bibit F0 terbaik diperoleh pada konsentrasi 15\%. Sedangkan pertumbuhan miselium bibit F0 yang paling tidak optimal, pada konsentrasi $20 \%$ saja.

58-Pertumbuhan Bibit F0... 


\section{Daftar Pustaka}

Achmad, Mugiono, Arlianti, Tias dan Azmi, Chotimatul. 2011. Panduan Lengkap Jamur. Depok: Panebar Swadaya.

Asegab, Muad. 2010. Bisnis Pembibitan Jamur Tiram, Jamur Merang dan Jamur Kuping. Jakarta: AgroMedia Pustaka.

Astuti, Novita Indri. 2017. Pertumbuhan Miselium Bibit F1 Jamur Tiram (Pleurotus ostreatus) dan Jamur Merang (Volvariella volvacea) pada Media Biji Kacang Tolo dan Biji Turi dari Bibit F0 Media Ubi Ungu. Skripsi. Universitas Muhammadiyah Surakarta.

Betharia, Nawangwulan Rhaina. 2017. Pemanfaatan Biji Nangka sebagai Media Alternatif untuk Pertumbuhan Bibit F0 Jamur Tiram dan Jamur Merang. Skripsi. Universitas Muhammadiyah Surakarta.

Handiyanto, Sugeng, Hastuti, Utami Sri dan Prabaningtyas, Sitoresmi. 2013. Kajian Penggunaan Air Cucian Beras sebagai Bahan Media Pertumbuhan Biakan Murni Jmur Tiram Putih (Pleurotus ostreatus var. florida). Skrpsi. Universitas Negeri Malang.

Lesmana, Agung, Triyanti, Merti dan Widiya, Mareta. 2016. Pengaruh Penambahan Tepung Beras Putih pada Media Potatoe Dextrose Agar (PDA) terhadap Miselium Biakan Murni Jamur Tiram Putih (Pleurotus ostreatus). Skripsi. STKIP PGRI Lubuklinggau.

Muyasarah, Fatimah. 2017. Pertumbuhan Bibit F0 Jamur Tiram dan Jamur Merang Pada Media Ubi Jalar Ungu. Skripsi. Universitas Muhammadiyah Surakarta.

Pertiwi, Anita Prabawati. 2017. Pemanfaatan Singkong sebagai Media Alternatif untuk Pertumbuhan Bibit F0 Jamur Tiram dan Jamur Merang. Skripsi. Universitas Muhammadiyah Surakarta.

Sainsjournal-fst11. 2015. Miselium Jamur Tiram Putih. http://sainsjournal-fst11.web.unair.ac.id/ artikel_detail-140062-MIKROBIOLOGI-Miselium\%20Jamur\%20Tiram\%20Putih.html. Diakses pada tanggal 23 Januari 2018.

Seswati, Ramza, Nurmiati dan Periadnadi. 2013. Pengaruh Pengaturan Keasaman Media Serbuk Gergaji Terhadap Pertumbuhan dan Produksi Jamur Tiram Coklat (Pleurotus cystidiosus O.K. Miller. Jurnal Biologi Universitas Andalas, 2(1). Hal: 31-36.

Setiadi, Yuwono, Sunarto, Hutagalung, Sihong P. 2015. Potensi Tepung Jewawut dalam Meningkatkan Kadar Fe dan Daya Terima Nugget Ayam. Jurnal Riset Kesehatan, 4(2). Hal: 756-762.

Singgih, Widian Dharma dan Harijono. 2015. Pengaruh Subtitusi Proporsi Tepung Beras Ketan Dengan Kentang Pada Pembuatan Wingko Kentang. Jurnal Pangan dan Agroindustri, 3 (4). Hal: 1573-1583.

Soeka, Yati Sudaryati dan Sulistiani. 2016. Profil Vitamin, Kalsium, Asam Amino dan Asam Lemak Tepung Jewawut (Setaria italica L.) Fermentasi. Jurnal Biologi Indonesia, 13(1). Hal: 85-96.

Sumarsih, Sri. 2010. Untung Besar Usaha Bibit Jamur Tiram. Depok: Panebar Swadaya

Sunarmi, Yohana Ipuk. 2010. Usaha 6 Jenis Jamur Skala Rumah Tangga. Jakarta: Panebar Swadaya.

Suparti, dan Nurul Karimawati. 2017. Pertumbuhan Bibit F0 Jamur Tiram dan Jamur Merang pada Media Umbi Talas dengan Konsentrasi yang Berbeda. Bioeksperimen, 3(1).Hal: 64-72.

Thongklang, N, et al. 2010. Culture Condition, Inoculum Production and Host Response of a Wild Mushroom Phlebopus portentosus Strain CMUHH121-005. Maejo International 
Journal of Science and Technology, 5(3). Pages: 413-425.

Tokopedia, 2018. Toko Laboratirium PDA MERCK. https://www.tokopedia.com/tokolaboratorium/ potato-dextrose-agar-500-g-merck-1101300500-pda-merck. Diakses pada tanggal 23 Januari 2018.

Utoyo, Norwiyono. 2010. Bertanam Jamur Kuping Di Lahan Sempit. Jakarta: AgroMedia Pustaka. Wiardani, Isnaen. 2010. Budi Daya Jamur Konsumsi. Yogyakarta: Lily Publisher.

Wijaya, Erinna Nydia. 2010. Pemanfaatan Tepung Jewawut (Pennisetum glaucum) dan Tepung Ampas Tahu dalam Formulasi Snack Bar. Skripsi. Institut Pertanian Bogor.

Yusron, Farid Nur. 2017. Pemanfaatan Umbi Kentang Hitam sebagai Media Alternatif untuk Pertumbuhan Bibit F0 Jamur Tiram dan Jamur Merang. Skripsi. Universitas Muhammadiyah Surakarta. 